\title{
Cellular and Molecular Events Leading to Mitochondrial Toxicity of 1-(2-Deoxy-2-Fluoro-1- $\beta$-D-Arabinofuranosyl)-5-lodouracil in Human Liver Cells
}

\author{
Lixin Cui, ${ }^{\star}$ Sahyun Yoon, ${ }^{*}$ Raymond F. Schinazi, ${ }^{\star \varsigma}$ and Jean-Pierre Sommadossi ${ }^{*}$ \\ * Department of Pharmacology and Toxicology, Division of Clinical Pharmacology, Comprehensive Cancer Center and Center for AIDS \\ Research, University of Alabama at Birmingham, Birmingham, Alabama 35294; ${ }^{\ddagger}$ Laboratory of Biochemical Pharmacology, Department \\ of Pediatrics, Emory University School of Medicine, Decatur, Georgia 30322; and ${ }^{\S}$ Georgia VA Research Center for AIDS and HIV \\ Infections, Veterans Affairs Medical Center, Decatur, Georgia 30033
}

\begin{abstract}
We have explored the mechanism(s) related to FIAU-induced liver toxicity, particularly focusing on its effect on mitochondrial function in a human hepatoma cell lineHepG2. The potential role of FMAU and FAU, metabolites detected in FIAU-treated patients were also ascertained. FIAU and FMAU inhibited cell growth and were effectively phosphorylated. A substantial increase in lactic acid production in medium of cells incubated with 1-10 $\mu$ M FIAU or FMAU was consistent with mitochondrial dysfunction. Slot blot analysis demonstrated that a two week exposure to 10 $\mu M$ FIAU or FMAU was not associated with a decrease in total mitochondrial (mt) DNA content. However, FIAU and FMAU were incorporated into nuclear and mtDNA and relative values suggest that both compounds incorporate at a much higher rate into mtDNA. Electron micrographs of cells incubated with $10 \mu M$ FIAU or FMAU revealed the presence of enlarged mitochondria with higher cristae density and lipid vesicles. In conclusion, these data suggest that despite the lack of inhibition of mtDNA content, incorporation of FIAU and FMAU into mtDNA of HepG2 cells leads to marked mitochondrial dysfunction as evidenced by disturbance in cellular energy metabolism and detection of
\end{abstract}

Address correspondence to Dr. Jean-Pierre Sommadossi, University of Alabama at Birmingham, University Station, Box 600, 1670 University Blvd., VH 113, Birmingham, AL 35294-0019. Phone: 205-934-8226; FAX: 205-975-4871. 1994.

Received for publication 25 May 1994 and in revised form 18 August

1. Abbreviations used in this paper: 3TC, (-)-2'-3'-dideoxy-3'-thiacytidine; AZT, 3'-azido-3'-deoxythymidine; ddC,2',3'-dideoxycytidine; ddI, 2', 3'-dideoxyinosine; dThd, thymidine; FAU, 1-(2-deoxy-2-fluoro$1-\beta$-D-arabinofuranosyl)-uracil; FHMAU, 1-(2-deoxy-2-fluoro-1- $\beta$-Darabinofuranosyl )-5-hydroxythymine; FIAC, 1-(2-deoxy-2-fluoro-1- $\beta$ D-arabinofuranosyl)-5-iodocytosine; FIAU, 1-(2-deoxy-2-fluoro-1- $\beta$ D-arabinofuranosyl)-5-iodouracil; FIAU-MP, FIAU-5'-monophosphate; FIAU-DP, FIAU-5'-diphosphate; FIAU-TP, FIAU-5'-triphosphate; FMAU, 1-(2-deoxy-2-fluoro-1- $\beta$-D-arabinofuranosyl)-5-thymine; FMAUDP, FMAU-5'-diphosphate; FMAU-MP, FMAU-5'-monophosphate; FMAU-TP, FMAU-5'-triphosphate; HBV, hepatitis B virus; LC/MS/ MS, liquid chromatography/mass spectrometry/mass spectrometry; mtDNA, mitochondrial DNA; TMP, thymidine-5'-monophosphate; TTP, thymidine-5'-triphosphate.

J. Clin. Invest.

(c) The American Society for Clinical Investigation, Inc. 0021-9738/95/02/0555/09 \$2.00

Volume 95, February 1995, 555-563 micro- and macrovesicular steatosis. (J. Clin. Invest. 1995. 95:555-563.) Key words: FIAU • FMAU • hepatitis B • liver toxicity $\cdot$ mitochondria

\section{Introduction}

Hepatitis B virus (HBV $)^{1}$ can cause chronic hepatitis in humans (1) and it is postulated that tumor development may be triggered directly by HBV or indirectly through chronic inflammation, cirrhosis, and cell regeneration associated with the infection (2). Approximately 300 million carriers are infected worldwide. The only therapy for this disease is interferon alpha which is effective in only $30 \%$ of patients with active liver disease, representing only a minority of infected individuals.

In 1990, a halogenated nucleoside analogue FIAU was found to have a potent in vivo activity against $\mathrm{HBV}$ infection in a chronically infected woodchuck animal model (3). Initial clinical studies of FIAU conducted in HIV infected persons with HBV co-infection for periods of 2 wk supported the animal data with a marked suppression of circulating HBV DNA (4). This effect lasted for several weeks after discontinuation of therapy (5). Two subsequent studies were then conducted in HIV negative HBV positive individuals. The first study involved a 4-wk course of therapy and no toxicity was noted. In a follow up clinical course trial in June, 1993, the death of 5 of the 15 enrolled patients, some of whom had received FIAU in the earlier 4-wk study, occurred after an 8-12-wk course therapy (6). In these patients, major clinical toxicities included liver failure with lactic acidosis, pancreatitis, neuropathy and myopathy $(5,6)$. The liver biopsies showed massive micro- and macrovesicular steatosis and the absence of glycogen as well as enlarged and irregular mitochondria under electron microscopy $(5,6)$. Liver mitochondrial damages subsequent to an inhibition of mtDNA synthesis by FIAU or incorporation of FIAU into the mitochondrial genome have been hypothesized as possible causes of that toxicity $(6,7)$. Of note, mitochondrial toxicity has already been suggested as being responsible for side-effects of some nucleoside analogs including peripheral neuropathy with ddC (8) and ddI (9) and myopathy with AZT (10). In contrast, we recently demonstrated that bone marrow toxicity of AZT, which is dose-limiting, is not related to inhibition of mtDNA content (11).

The purpose of this study was to explore the cellular and molecular events related to FIAU-induced liver toxicity, particularly focusing on its effect on mitochondrial functions. The human hepatoma HepG2 cell line isolated by Aden et al. (12) and the 2.2.15 cell line which consists of HepG2 cells transfected with HBV (13) were selected for these investigations since the HepG2 cell line retains many characteristics of hepatocytes, is an adequate in vitro model in which to examine 
liver functions $(14,15)$, and can be transfected with HBV leading to production of infectious virions (13). Only scant data have been reported on the in vitro and in vivo metabolism of FIAU but more extensive investigations have been carried out with FIAC, a nucleoside extensively deaminated in vivo to FIAU (16-18). From these studies, it is clear that several metabolites of FIAU can be formed including FAU, FMAU, FHMAU and glucuronides of FIAU and FMAU (16-18). Unpublished data from our laboratory substantiates these previous reports and LC/MS/MS analysis of biological specimens of FIAU-treated patients from the last clinical trial demonstrates that FIAU is substantially metabolized to FAU and FMAU (19). Since it is possible that these metabolites may also have contributed to the liver induced toxicity observed in treated patients, effects of these FIAU metabolic derivatives were also investigated in HepG2 cells.

\section{Methods}

Materials. The HepG2 cell line was purchased from the American Type Culture Collection (Rockville, MD) and HBV-transfected 2.2.15 cells were obtained from Dr. G. Acs (Mt. Sinai Medical Center, New York). 3TC was obtained from Dr. Raymond F. Schinazi (Emory University, Decatur, GA). FIAU, FAU, and FMAU were obtained from Dr. J. J. Fox (Memorial Sloan-Kettering Cancer Center, New York). FIAU and FMAU nucleotides were synthesized in our laboratory according to standard phosphorylation procedures published previously (20). [2${ }^{14} \mathrm{C}$ ]-FIAU ( $\left.56 \mathrm{mCi} / \mathrm{mmol}\right)$ and [ methyl- $\left.{ }^{3} \mathrm{H}\right]$-FMAU $(400 \mathrm{mCi} / \mathrm{mmol})$ were purchased from Moravek Biochemicals (Brea, CA). MEM with non-essential amino acids, sodium pyruvate, dialyzed fetal bovine serum and $10 \times$ trypsin-EDTA were purchased from GIBCO BRL (Grand Island, NY). Lactic acid assay kit was purchased from Boehringer Mannheim Corp. (Mannheim, Germany). Luciferin-luciferase was obtained from Calbiochem Corp. (La Jolla, CA). Alkaline phosphatase, DNase I and snake venom $5^{\prime}$-phosphodiesterase were purchased from Sigma Chemical Co. (St. Louis, MO). All other chemicals and reagents were of the highest analytical grade available.

Cell conditions. The HepG2- and HBV-transfected 2.2.15 cells were grown in 25 or $75 \mathrm{~cm}^{2}$ tissue culture flasks in MEM with non-essential amino acids supplemented with $10 \%$ heat-inactivated dialyzed fetal bovine serum, $1 \%$ sodium pyruvate, and $1 \%$ penicillin/streptomycin. The medium was changed every three days and cells were subcultured once a week.

Effects of compounds on cell growth. The HepG2 cells from stock culture were diluted and plated into 12-well cell culture clusters with 2.5 $\times 10^{4}$ cells $/ \mathrm{ml}$ in each well. Various concentrations of FIAU, FMAU, FAU or no compound (control) were added in media to each well. After $4 \mathrm{~d}$ of incubation, fresh medium with the tested compound was changed every other day until termination of the experiment at $14 \mathrm{~d}$. Every other day the cells in one cell culture cluster were removed from the bottom of each well by using $0.05 \%$ trypsin- $0.02 \%$ EDTA and counted with a hemocytometer under the microscope. Cell viability, as assessed by trypan blue exclusion, was $95 \%$ or greater during experiments.

Determination of intracellular phosphorylated metabolites. Confluent HepG2 or 2.2 .15 cells $\left(2 \times 10^{6}\right.$ cells $\left./ \mathrm{ml}\right)$ were suspended in a total volume of $10 \mathrm{ml}$ medium per time period in 25 or $75 \mathrm{~cm}^{2}$ tissue culture flask. After addition of radiolabeled ${ }^{14} \mathrm{C}$-FIAU $(124 \mathrm{dpm} / \mathrm{pmole})$ or ${ }^{3} \mathrm{H}$ FMAU ( $888 \mathrm{dpm} /$ pmole $)$ at a final concentration $\sim 2 \mu \mathrm{M}$, cells were maintained at $37^{\circ} \mathrm{C}$ under a $5 \% \mathrm{CO}_{2}$ atmosphere for specified time periods. At the selected time points $(6,24,48,72,96 \mathrm{~h})$, cells were centrifuged at 1,200 rpm for $10 \mathrm{~min}$ in a Beckman GPR centrifuge, and were washed three times with $10 \mathrm{ml}$ of cold phosphate-buffered saline. Nucleotides present in the cell pellet were extracted by incubation overnight at $-20^{\circ} \mathrm{C}$ with $1 \mathrm{ml}$ of $60 \%$ methanol and were then extracted with $500 \mu \mathrm{l}$ of $60 \%$ methanol for $30 \mathrm{~min}$ in an ice bath. Combined extracts were dried under a gentle nitrogen stream at room temperature and the samples were stored at $-20^{\circ} \mathrm{C}$ until analysis. Separation of nucleotides was performed on a Hewlett-Packard 1050 HPLC system (Avondale, PA). The extracts were analyzed by anion exchange chromatography with a Partisil $10 \mathrm{SAX}$ column (Jones Chromatography, Lakewood, CO). Elution was carried out at $1 \mathrm{ml} / \mathrm{min}$ with $15 \mathrm{mM}$ $\mathrm{KH}_{2} \mathrm{PO}_{4}$ (pH 3.5) and a 45 min linear gradient of $1 \mathrm{M} \mathrm{KH}_{2} \mathrm{PO}_{4}(\mathrm{pH}$ 3.5 ) from 0 to $100 \%$, starting $10 \mathrm{~min}$ after the time of injection. The total running time was $70 \mathrm{~min}$. Under the conditions defined above, the retention times of the unlabeled markers of FIAU, FIAU-MP, FIAUDP, FIAU-TP were 4, 18, 29, and 44 min, respectively. The retention times of FMAU, FMAU-MP, FMAU-DP and FMAU-TP were 3, 10, 26 , and $41 \mathrm{~min}$, respectively. After fractionation $(1 \mathrm{ml})$ of the eluate and addition of scintillation fluor $(5 \mathrm{ml})$, radioactivity was measured by using a Beckman LS5000 TA scintillation counter equipped with an automatic quench correction program. Reverse phase chromatography was used to separate FIAU, FMAU, and FAU. Samples were examined using Hypersil C-18 5 $\mu \mathrm{m}$ (Jones Chromatography, Lakewood, CO) as stationary phase. Elution was carried out isocratically at $1 \mathrm{ml} / \mathrm{min}$ with $25 \mathrm{mM} \mathrm{KH}_{2} \mathrm{PO}_{4}(\mathrm{pH} 2.6)$ and $12 \%$ methanol. The retention times of authentic standards of FAU, FMAU, and FIAU were 7.4, 16.5, and 28.2 min, respectively.

Mitochondria isolation and phosphorylation studies. A 1-ml pellet of HepG2 cells was washed with cold $20 \mathrm{ml}$ buffer containing $134 \mathrm{mM}$ $\mathrm{NaCl}, 5 \mathrm{mM} \mathrm{KCl}, 0.7 \mathrm{mM} \mathrm{Na}_{2} \mathrm{HPO}_{4}, 2.5 \mathrm{mM}$ Tris at pH 7.5 and subsequently centrifuged for $5 \mathrm{~min}$ at $2,500 \mathrm{rpm}$ and $4^{\circ} \mathrm{C}$ in a Beckman GPR centrifuge. Cells were then resuspended at $4^{\circ} \mathrm{C}$ in $12 \mathrm{ml}$ of buffer containing $10 \mathrm{mM} \mathrm{NaCl}, 1.5 \mathrm{mM} \mathrm{MgCl} 2$ and $10 \mathrm{mM}$ Tris at $\mathrm{pH} 7.5$ and incubated for $10 \mathrm{~min}$. Swollen cells were disrupted with a glass Dounce homogenizer and one-sixth volume of cold $2 \mathrm{M}$ sucrose, 35 $\mathrm{mM}$ EDTA, $50 \mathrm{mM}$ Tris solution ( $\mathrm{pH} 7.5$ ) was added immediately to stabilize mitochondria against osmotic rupture. Nuclei were then eliminated by two successive sedimentations of $4 \mathrm{~min}$ each at 2,500 $\mathrm{rpm}$ in a Beckman GPR centrifuge. The resulting supernatant was centrifuged at 14,000 rpm for $20 \mathrm{~min}$ in a Beckman $J_{2-} 20$ centrifuge to obtain the mitochondrial pellet.

The mitochondrial pellet ( $600 \mu \mathrm{g}$ protein/sample) was resuspended in incubation buffer containing $10 \mathrm{mM}$ succinate, $2 \mathrm{mM}$ ATP, $2 \mathrm{mM}$ pyruvate, $1 \mathrm{mM}$ malate, $2 \mathrm{mM}$ nicotinic acid, $10 \mathrm{mM} \mathrm{MgCl}_{2}, 2 \mathrm{mM}$ $\mathrm{KCl}, 10 \mathrm{mM} \mathrm{KH}_{2} \mathrm{PO}_{4}$, and $25 \mathrm{mM}$ Tris- $\mathrm{HCl}$ at $\mathrm{pH} 8$. Experiments were initiated with addition of ${ }^{3} \mathrm{H}$-FMAU ( $\left.888 \mathrm{dpm} / \mathrm{pmole}\right)$ or ${ }^{14} \mathrm{C}$-FIAU (124 dpm/pmole) to achieve a final concentration of $10 \mu \mathrm{M} .\left[{ }^{3} \mathrm{H}\right]-$ Thymidine $(1,000 \mathrm{dpm} /$ pmole $)$ was used as positive control. After 30 $\mathrm{min}$ at $37^{\circ} \mathrm{C}$, mitochondria were centrifuged at $15,000 \mathrm{~g}$ for $5 \mathrm{~min}$ and washed three times with cold washing buffer containing $0.25 \mathrm{mM}$ sucrose and $1 \mathrm{mM}$ EDTA. Extraction of intra-mitochondrial nucleotides and HPLC analysis was performed with a similar procedures used for intracellular nucleotide determination as described above.

Effect of compounds on mtDNA content. After $14 \mathrm{~d}$ of incubation, cells $\left(5 \times 10^{4}\right.$ per sample $)$ incubated with varying concentrations of FIAU or FMAU and no compound (control) were heated under alkaline condition and the DNA was immobilized on a Zeta-Probe membrane (Bio-Rad, Richmond, CA) by using a slot-blot apparatus. The mtDNA on the membrane was detected with a specific human oligonucleotide mitochondrial probe, encompassing nucleotide positions 4212-4242 (21). A gel-purified 625-base pair fragment of a human beta-actin cDNA plasmid was used as a probe for standardizing the amount of total cellular DNA loaded on the membrane.

Incorporation of FIAU and FMAU into nuclear and mtDNA of HepG2 cells. Confluent cells $\left(10^{6}\right.$ cells $\left./ \mathrm{ml}\right)$ were incubated at $37^{\circ} \mathrm{C}$ for $4 \mathrm{~d}$ after addition of ${ }^{14} \mathrm{C}$-FIAU ( $124 \mathrm{dpm} /$ pmole) or ${ }^{3} \mathrm{H}$-FMAU ( 888 $\mathrm{dpm} / \mathrm{pmole}$ ) to achieve a final concentration of $2 \mu \mathrm{M}$. Cells were then harvested and washed twice at $4^{\circ} \mathrm{C}$ with cell culture media. Total nuclear DNA was isolated as previously described in detail (22). Mitochondrial DNA was prepared from purified mitochondria by a modified procedure of Welter et al. (23). All steps described below were performed at $4^{\circ} \mathrm{C}$.

Briefly, the cell pellet was homogenized in a buffer containing 0.25 M sucrose, $130 \mathrm{mM} \mathrm{KCl}, 30 \mathrm{mM}$ Tris- $\mathrm{HCl}, \mathrm{pH} 7.6,3 \mathrm{mM} \mathrm{Mg}$ acetate $1 \mathrm{mM}$ DTT and then centrifuged at 1,200 rpm for $5 \mathrm{~min}$ in a Beckman GPR centrifuge. The supernatant, which included unpelleted mitochondria was aspirated and recentrifuged in the same manner. The mitochon- 
dria in the supernatant were then layered on top of the sucrose gradient which consisted of three concentrations of $1.0,1.2$, and $1.6 \mathrm{M}$ sucrose containing $10 \mathrm{mM}$ Tris- $\mathrm{HCl}, \mathrm{pH} 7.6,1 \mathrm{mM}$ EDTA, and $0.1 \%$ bovine serum albumin and centrifuged at $28,000 \mathrm{rpm}$ for $3 \mathrm{~h}$ in a Beckman L8 ultracentrifuge. Three distinct bands appeared on each gradient interface. The middle band (between 1.0 and $1.2 \mathrm{M}$ sucrose gradient), which represented the purified fraction of mitochondria was aspirated and diluted with water to reduce the density and subsequently centrifuged at $12,000 \mathrm{rpm}$ for $30 \mathrm{~min}$ in a Beckman L8 ultra centrifuge to pellet the mitochondria. This pellet was used to isolate the mtDNA according to similar methods described above for cellular DNA. Radioactivity incorporated into nuclear and mt DNA was determined in a Beckman LS $5000 \mathrm{TA}$ counter. To assess the purity of isolated mtDNA, the same amount of mt DNA which was used to determine radioactivity, was analyzed by $0.8 \%$ agarose gel electrophoresis in the presence and absence of Ava II restriction enzyme.

Enzymatic digestion of radiolabeled nuclear and mitochondrial DNA. ${ }^{14} \mathrm{C}$ - or ${ }^{3} \mathrm{H}$-radiolabeled nuclear DNA was hydrolyzed with DNAse I ( 22 $\mathrm{U}$ ) at $37^{\circ} \mathrm{C}$ for $1 \mathrm{~h}$ and digestion was confirmed by electrophoresis analysis. Reaction volume was adjusted to $200 \mu \mathrm{l}$ with $20 \mu \mathrm{l}$ of $10 \times$ phosphodiesterase I buffer (1.1 M Tris-HCl, $\mathrm{pH} 9.0,1.1 \mathrm{M} \mathrm{NaCl}, 0.15 \mathrm{M} \mathrm{MgCl}_{2}$ ) including $0.5 \mathrm{U}$ of snake venom $5^{\prime}$-phosphodiesterase. After incubation at $37^{\circ} \mathrm{C}$ for $4 \mathrm{~h}, 3 \mathrm{U}$ of alkaline phosphatase were added in a final reaction volume of $300 \mu \mathrm{l}$ including $0.5 \mathrm{M}$ tris- $\mathrm{HCl}, \mathrm{pH} 9.3,10 \mathrm{mM} \mathrm{MgCl}, 1$ $\mathrm{mM} \mathrm{ZnCl}$, and $10 \mathrm{mM}$ spermidine. This reaction was carried out at $37^{\circ} \mathrm{C}$ for $1 \mathrm{~h}$. The digested material was then analyzed by the reverse phase HPLC method described above. Hydrolysis of mtDNA was performed under similar conditions as described for nuclear DNA except that reaction volume and amount of enzyme were decreased by half.

Lactic acid determination. HepG2 cells $\left(2.5 \times 10^{4}\right.$ cells $\left./ \mathrm{ml}\right)$ were plated into 12-well cell culture clusters and treated with various concentrations of FIAU or FMAU under similar conditions described above. After 2 and $4 \mathrm{~d}$ of incubation, cell number in each well was determined with a hemocytometer, and medium was collected and filtered by using Acro disc LC13 PVDF from Fisher Scientific (Pittsburgh, PA). The lactic acid content in the medium was measured using a Boerhinger lactic acid assay kit, following the supplier's instructions. The amount of lactic acid in the medium was expressed as $\mathrm{mg}$ of lactic acid production per $10^{6}$ cells $(24)$.

Cell ATP determination by luciferase assay. HepG2 cells were incubated under similar conditions described above. After $4 \mathrm{~d}$, one set of cell culture was used to measure cell number and the other to extract the total ATP content with $1 \mathrm{ml}$ of ice-cold $0.4 \mathrm{M}$ perchloric acid over a 20-min incubation period (25). Luminescence was measured by using a Beckman LS 7500 scintillation counter in the noncoincidence mode. For each sample, $50 \mu \mathrm{l}$ of diluted PCA extract was added to $1 \mathrm{ml}$ arsenate buffer $(0.1 \mathrm{M}$ sodium arsenate, $40 \mathrm{mM}$ magnesium sulphate, $\mathrm{pH} 7.4$ ), $1 \mathrm{ml}$ PBS ( $\mathrm{pH} \mathrm{7.4)} \mathrm{and} 1 \mathrm{ml}$ distilled water in a glass scintillation vial. The reaction was started by the addition of $100 \mu \mathrm{l}$ of luciferinluciferase and the vial was quickly transferred to the scintillation counter $(25,26)$. Standard curves were linear over concentrations of ATP comprised between 5 and 75 pmol. The total ATP content within cell was expressed as nmol of ATP per $10^{6}$ cells.

Morphological evaluation. HepG2 cells $\left(2.5 \times 10^{4}\right.$ cells $\left./ \mathrm{ml}\right)$ were plated into $35 \times 10-\mathrm{mm}$ tissue culture dishes and $10 \mu \mathrm{M}$ FIAU or FMAU or no compound (control) were added to each dish. After a 4d incubation period, medium with and without (control) compounds was changed every other day. At selected time points (day, 2, 4, 7, and 12 ), cells were fixed in $1 \%$ glutaraldehyde for one hr, rinsed in sodium phosphate buffer and post-fixed in $1 \%$ osmium tetroxide for $1 \mathrm{~h}$. The cells were gradually dehydrated with graded concentrations of ethanol starting with $50 \%$ through $100 \%$ ethanol to propylene oxide and subsequently slowly infiltrated with epon (embedding medium) and embedded in epon. Lastly, cells were sectioned with a Reichert-Jung ultramicrotome, stained with uranyl acetate and lead citrate, and examined with a Hitachi 7000 electron microscope.

\section{Results}

Effect of FIAU, FMAU, and FAU on HepG2 cell proliferation. HepG2 cell growth was assessed in the presence of various
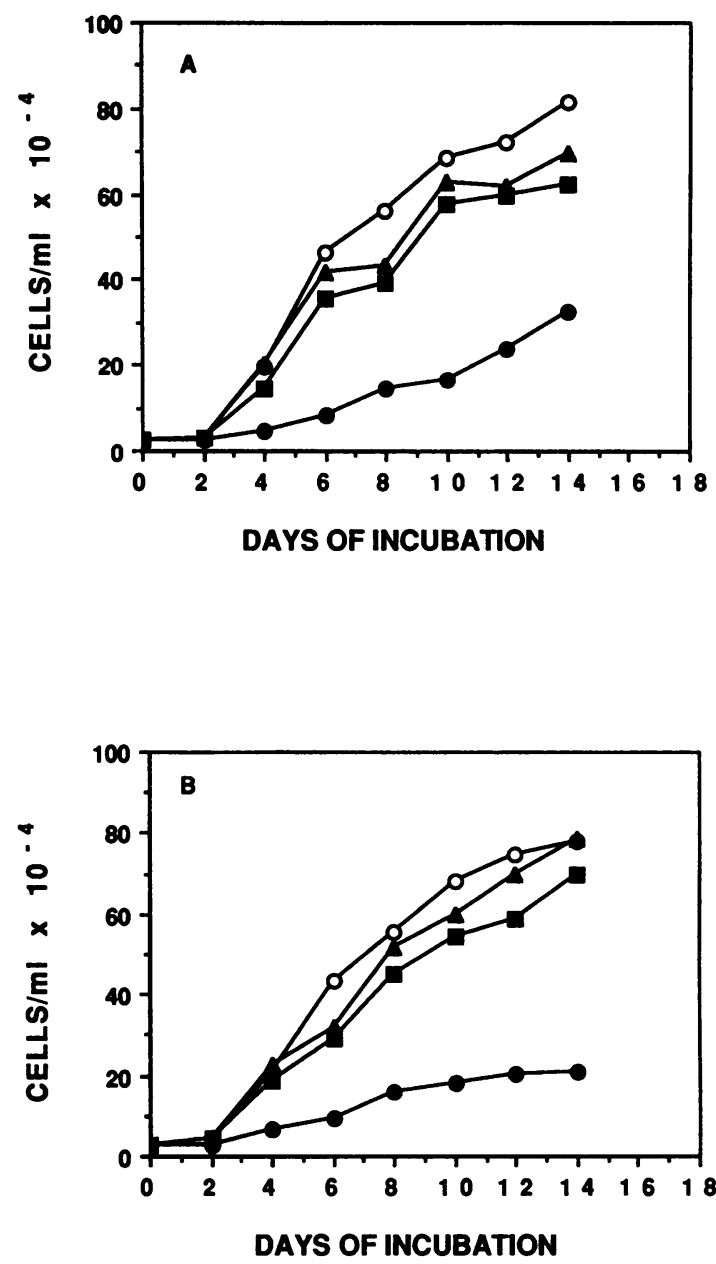

Figure 1. HepG2 cell growth over a 14-d time period in the absence $(O$, control) and in the presence of $0.1(\Delta), 1(\square)$, and $10(\bullet) \mu \mathrm{M}$ FIAU $(A)$ or FMAU $(B)$. Each point represents the mean of two experiments.

concentrations of FIAU, FMAU, and FAU as described in Methods. Under these conditions, both FIAU and FMAU inhibited cell growth in a dose-dependent manner, with a pronounced effect at concentrations comprised between 1 and $10 \mu \mathrm{M}$ (Fig. $1, A$ and $B$ ). After 6 and $14 \mathrm{~d}$ of incubation, the $\mathrm{IC}_{50}$ values for FIAU and FMAU were 2.1 and $5.5 \mu \mathrm{M}$, and 1.4 and 4.0 $\mu \mathrm{M}$ respectively. In contrast, FAU had no inhibitory effect on cell proliferation at concentrations up to $10 \mu \mathrm{M}$.

Metabolism of FIAU and FMAU in HepG2 and HBV transfected 2.2.15 cells. Confluent HepG2 and HBV transfected 2.2.15 cells were exposed to $2.5 \mu \mathrm{M}{ }^{14} \mathrm{C}$-FIAU or $2.5 \mu \mathrm{M}{ }^{3} \mathrm{H}$ FMAU over a 4-d time period. Both FIAU and FMAU were rapidly phosphorylated within cells to their 5'-mono-, 5'-di-, and 5 ' - triphosphate derivatives, as analyzed by anion exchange chromatography. The intracellular concentrations of FIAU and FMAU 5'-phosphorylated derivatives after 6-, 24-, 48-, 72-, and 96-h incubation periods are illustrated in Table I. By 6 $h$, FIAU-TP was the predominant intracellular metabolite and reached a mean concentration of $0.37 \mathrm{pmol} / 10^{6}$ cells, and an equilibrium approximating $0.3 \mathrm{pmol} / 10^{6}$ cells was maintained for the remaining $90 \mathrm{~h}$ of the experiment. Meanwhile, FIAUMP and FIAU-DP reached their maximum peaks at $48 \mathrm{~h}$, and subsequently slowly declined with concentrations below that of 
Table I. Intracellular Concentration of FIAU- and FMAU-5'Phosphorylated Derivatives in Hep-G2 Cells after Exposure to $2.5 \mu M{ }^{14} \mathrm{C}$-FIAU or ${ }^{3} \mathrm{H}-\mathrm{FMAU}$

\begin{tabular}{cllcr}
\hline \multirow{2}{*}{$\begin{array}{c}\text { Time of } \\
\text { exposure }\end{array}$} & Treatment & MP & DP & TP \\
\cline { 3 - 5 }$h$ & & & pmol/10 cells \\
& & & & \\
\multirow{2}{*}{6} & FIAU & 0.04 & 0.06 & 0.33 \\
& FMAU & 0.27 & 0.43 & 0.36 \\
24 & FIAU & 0.08 & 0.08 & 0.31 \\
& FMAU & 0.13 & 0.29 & 0.36 \\
48 & FIAU & 0.25 & 0.10 & 0.36 \\
& FMAU & 0.15 & 0.17 & 0.38 \\
& FIAU & 0.12 & 0.08 & 0.31 \\
& FMAU & 0.15 & 0.19 & 0.36 \\
& FIAU & 0.10 & 0.07 & 0.26 \\
& FMAU & 0.12 & 0.20 & 0.36 \\
& & & & \\
\hline
\end{tabular}

Values are mean of two experiments.

FIAU-TP at any time of exposure. FMAU was also rapidly phosphorylated to its 5'-mono-, 5'-di-, and 5'-triphosphate. By $6 \mathrm{~h}$, both FMAU-MP and FMAU-DP were already at their highest intracellular levels and FMAU-TP accumulated to concentration comprised between 0.3 and $0.4 \mathrm{pmol} / 10^{6}$ cells. In general, FMAU generated slightly higher $5^{\prime}$-triphosphate metabolite concentrations than FIAU. Using HBV-transfected 2.2.15 cells, similar concentrations of phosphorylated metabolites were obtained with either FIAU or FMAU as compared to non-infected HepG2 cells (data not shown). Further analysis by reverse phase chromatography of extracellular medium of 2.2.15 cells $48 \mathrm{~h}$ after exposure of cells to FIAU revealed that 14 to $15 \%$ of FIAU was intracellularly converted to FAU which was then released in medium while no FMAU was detected. Under similar conditions, FMAU remained unmetabolized and no other derivative was detected.

Determination of FIAU and FMAU phosphorylation in isolated mitochondria of HepG 2 cells. Before performing the experiment, a glucose 6-phosphatase assay was conducted to detect the presence of cytosol in the mitochondrial fraction. Release of free phosphate was insignificant indicating a very low percentage of cytosolic entities. A positive control performed with $10 \mu \mathrm{M}\left[{ }^{3} \mathrm{H}\right]$ thymidine demonstrated conversion to its $5^{\prime}$ phosphorylated derivatives, including thymidine-5'-triphosphate (Fig. $2 A$ ). In contrast, no 5 '-phosphorylated derivatives were detected when ${ }^{14} \mathrm{C}$-FIAU (Fig. $2 B$ ) or ${ }^{3} \mathrm{H}$-FMAU (Fig. 2 $C$ ) were incubated with mitochondria under similar conditions.

Incorporation of FIAU and FMAU into nuclear and $m t D N A$. To evaluate the interaction of FIAU and FMAU with total DNA, confluent HepG2 cells were exposed for $4 \mathrm{~d}$ to radiolabeled ${ }^{14} \mathrm{C}$-FIAU or ${ }^{3} \mathrm{H}$-FMAU at a final concentration of $2 \mu \mathrm{M}$. Both nuclear and mtDNA were isolated, purified and analyzed as described in Methods. Identification and purity of mtDNA was performed by analysis with a $0.8 \%$ agarose gel electrophoresis in the presence and absence of Ava II restriction enzyme. As illustrated in Fig. 3, lane 2, a unique mtDNA band appeared at the expected size range of $16.5 \mathrm{~kb}$ when compared with molecular weight markers IV (Fig. 3, lane 1). This mtDNA was also shown to retain expected cleavage sites for Ava II (Fig. 3, lane 3 ) as previously published (27). To determine quantitatively
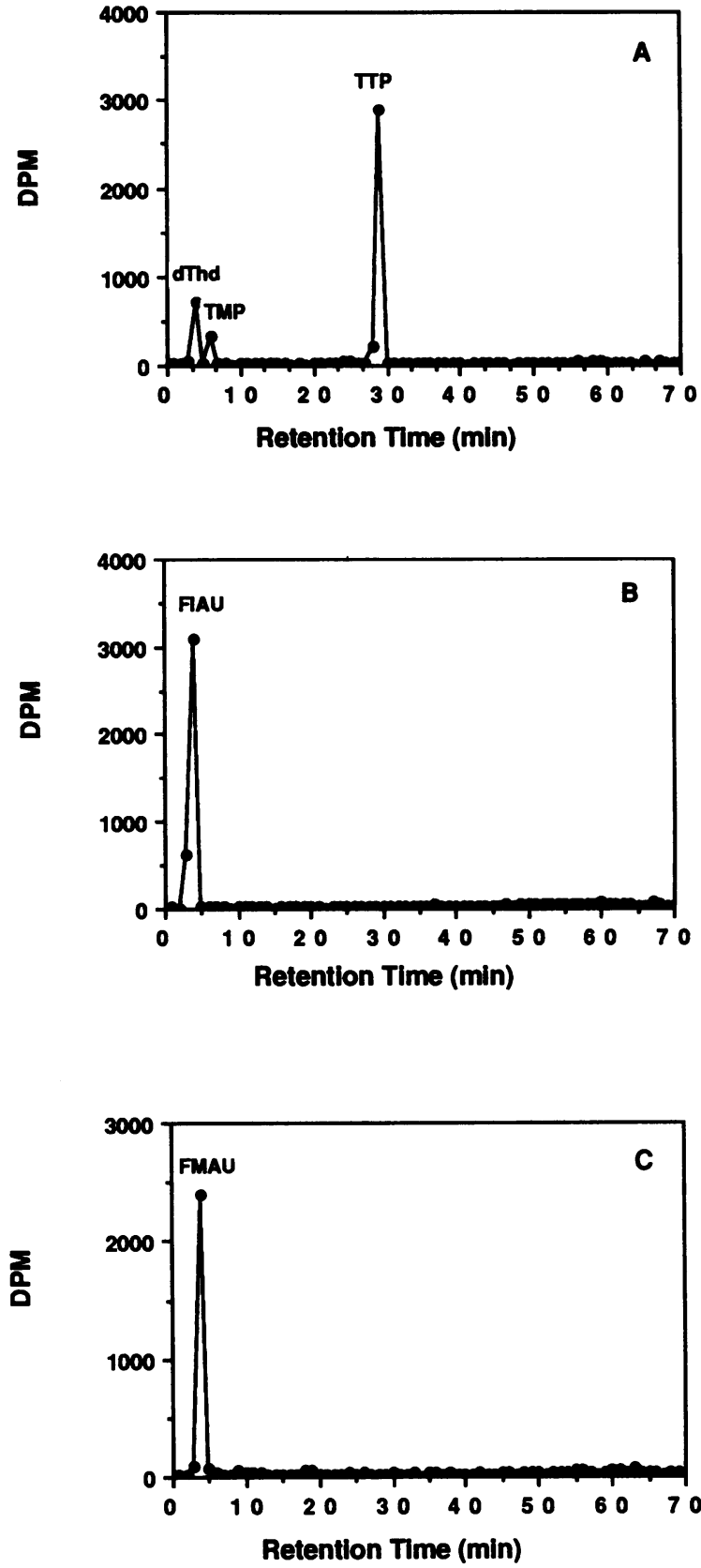

Figure 2. Anion exchange HPLC analysis of radioactivity after exposure of isolated mitochondria of HepG2 cells with $\left[{ }^{3} \mathrm{H}\right]$ thymidine $(A),{ }^{14} \mathrm{C}$ FIAU $(B)$, and ${ }^{3} \mathrm{H}-\mathrm{FMAU}(C)$.

the amount of radioactivity incorporated into nuclear and mtDNA, as a function of 4-d exposure to cells with $2 \mu \mathrm{M}$ FIAU or FMAU, radioactivity was measured in purified nuclear and mtDNA as described in Methods. FIAU was incorporated into both nuclear and mtDNA with values of 90 and $9.6 \mathrm{pmole} / \mu \mathrm{g}$ DNA respectively. The amount of FMAU incorporated into nuclear DNA was $45.6 \mathrm{pmole} / \mu \mathrm{g}$ DNA, being about twofold lower as compared with that observed with FIAU, whereas a modest increase of FMAU incorporation into mtDNA was observed with a value of $11.5 \mathrm{pmole} / \mu \mathrm{g}$ DNA. Identification of the radioactivity detected in nuclear and mtDNA was performed by enzymatically hydrolyzing the DNA to nucleoside with subsequent HPLC analysis. Fig. 4 shows the radiochro- 


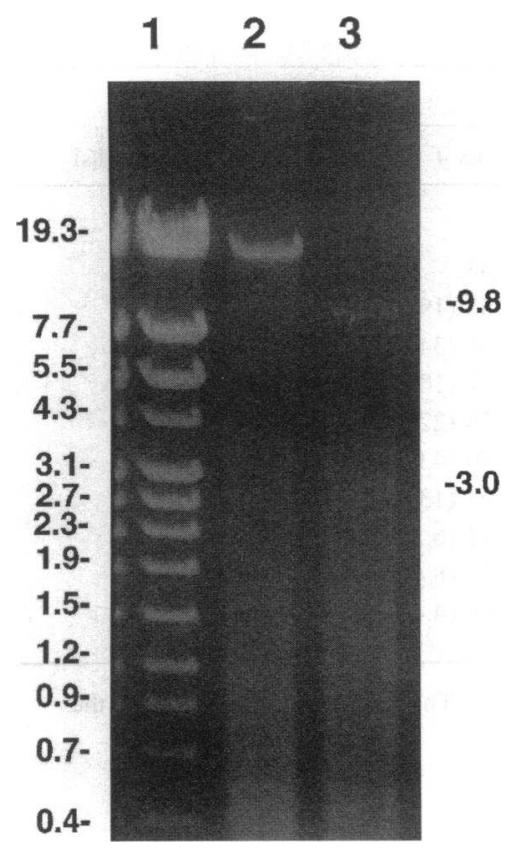

Figure 3. Gel electrophoresis of mtDNA. Isolation of mtDNA from HepG2 cells was performed as described in Methods. MtDNA was treated in the presence and absence of restriction enzyme (Ava II) and fractionated by electrophoresis on a $0.8 \%$ agarose gel and visualized by ethidium bromide staining. Lane 1, molecular weight marker IV, Boehringer-Mannheim; lane 2 , undigested mtDNA; lane 3, mtDNA Ava II fragments.

matograms of enzymatically digested nuclear $(A$ and $B)$ and mitochondrial ( $C$ and $D$ ) DNA after exposure of cells to either ${ }^{14} \mathrm{C}$-FIAU or ${ }^{3} \mathrm{H}$-FMAU. More than $94 \%$ of ${ }^{14} \mathrm{C}$ radioactivity in both nuclear and mtDNA coeluted with an authentic standard of FIAU and the remainder coeluted with FMAU (1.5\%) and FAU (3.5\%) standards. In contrast, all ${ }^{3} \mathrm{H}$-radioactivity coeluted with an authentic FMAU standard.

Effect of FIAU and FMAU on mtDNA content, extracellular lactic acid levels and total ATP content in HepG2 cells. Table II shows that FMAU exposed to HepG 2 cells for $14 \mathrm{~d}$ had no effect on mtDNA content at concentrations up to $10 \mu \mathrm{M}$, while FIAU only caused a $14 \%$ decrease in mtDNA content at a concentration of $10 \mu \mathrm{M}$. To observe the effect of FIAU and FMAU on mitochondrial function, the lactic acid content in HepG2 cell culture medium was determined. Table II demonstrates that both FIAU and FMAU induced increased lactic acid production in HepG2 cells in a dose-dependent manner. After $2 \mathrm{~d}$ of incubation, enhancement in lactic acid production was detected at concentrations of $1 \mu \mathrm{M}$ and predominately $10 \mu \mathrm{M}$, with both compounds. After incubation for $4 \mathrm{~d}$, there was a more profound effect in lactic acid production, resulting in a twofold increase as compared with control when cells were exposed to $10 \mu \mathrm{M}$ FIAU or FMAU. In contrast, under similar conditions, 3TC at concentrations comprised between 0.1 and $10 \mu \mathrm{M}$ had no substantial effect on lactic acid production. As described in Methods, HepG2 cells were incubated in the presence of various concentrations of FIAU or FMAU for $4 \mathrm{~d}$. After extraction with $0.4 \mathrm{M}$ ice-cold perchloric acid, the total (cellular and mitochondrial) ATP content was measured by using a luciferase assay. Both FIAU and FMAU induced, in a dose-dependent manner and to a similar degree, an increase of total ATP content in HepG2 cells, suggesting a disturbance in energy metabolism (Table II).

Electron microscopy evaluation. HepG2 cells incubated for $4 \mathrm{~d}$ with $10 \mu \mathrm{M}$ FIAU or FMAU, as described in Methods, were examined by electron microscopy. Electron micrographs clearly delineate the formation of a large amount of lipid vesicles within cells treated with FIAU (Fig. $5 B$ ) and FMAU (Fig. $5 C$ ) relative to control cells (Fig. $5 A$ ). In addition, mitochondria of cells incubated with either FIAU (Fig. $6 B$ ) or FMAU (data not shown) were enlarged and displayed a higher cristae density as compared with control (Fig. $6 \mathrm{~A}$ ). In contrast, 3TC-treated cells did not induce any apparent morphological changes under the same conditions (data not shown).

\section{Discussion}

FIAU, a nucleoside fluorinated in the carbohydrate moiety synthesized in the 1970s (28) and initially developed for treatment
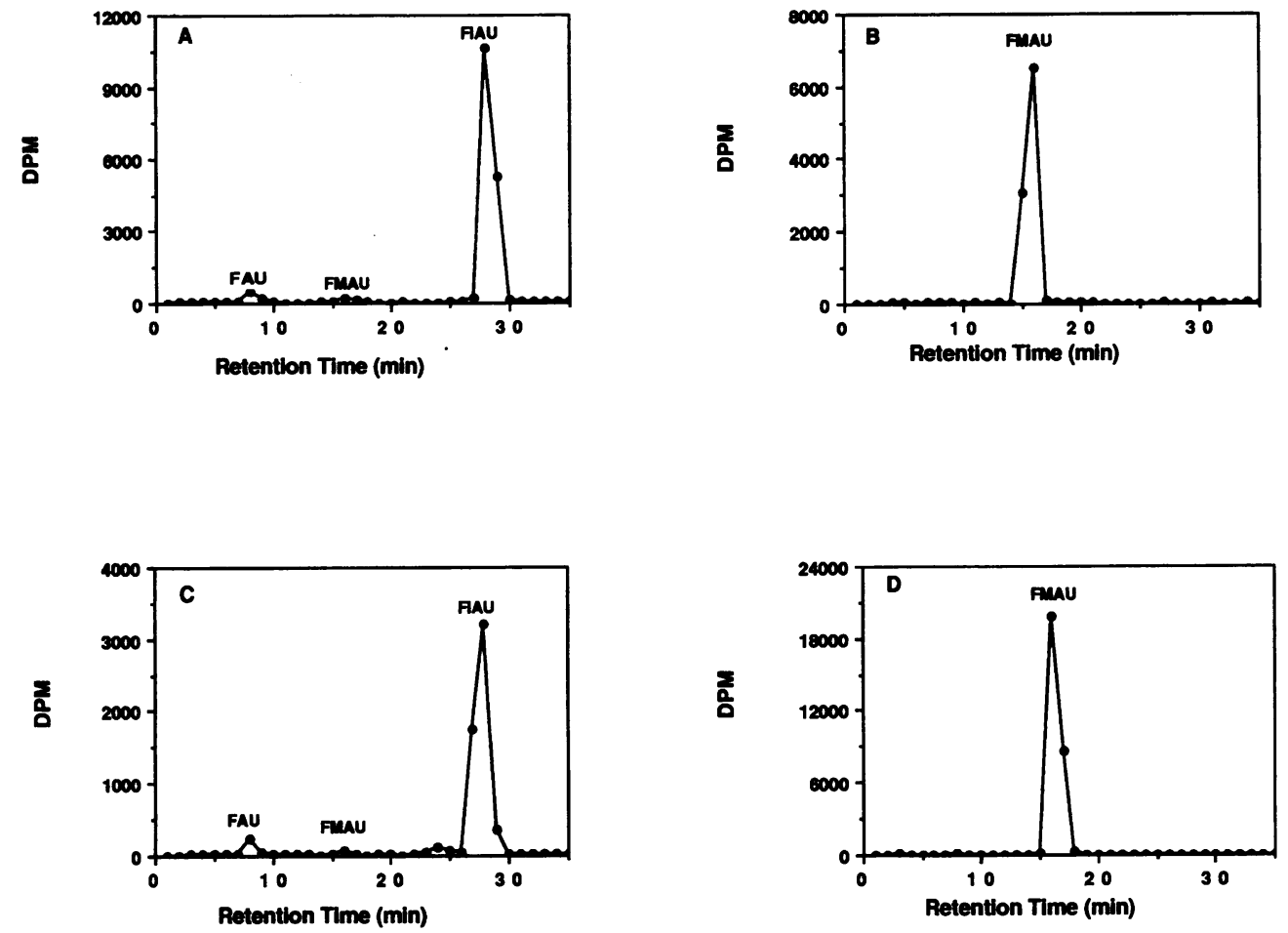

Figure 4. Reverse phase HPLC analysis of ${ }^{14} \mathrm{C}$-labeled digested nuclear DNA $(A)$ and mtDNA $(C)$ isolated from HepG2 cells exposed to $2 \mu \mathrm{M}{ }^{14} \mathrm{C}$-FIAU for $4 \mathrm{~d}$; ${ }^{3} \mathrm{H}$-labeled digested nuclear DNA $(B)$ and mtDNA $(D)$ isolated from HepG2 cells exposed to 2 $\mu \mathrm{M}{ }^{3} \mathrm{H}$-FMAU for $4 \mathrm{~d}$. DNA digestion was performed by the sequential addition of DNAse I, snake venom 5 '-phosphodiesterase and alkaline phosphatase. 
Table II. Effect of FIAU and FMAU on Mitochondrial Functions in Hep-G2 Cells

\begin{tabular}{|c|c|c|c|c|c|}
\hline \multirow[b]{2}{*}{ Compound } & \multirow[b]{2}{*}{ Concentration } & \multirow{2}{*}{$\begin{array}{l}\text { Ratio to control of } \\
\text { mtDNA synthesis }\end{array}$} & \multicolumn{2}{|c|}{ Lactic acid production } & \multirow{2}{*}{$\begin{array}{c}\text { ATP content } \\
\left(\mathrm{mmol} / 10^{6} \text { cells }\right)\end{array}$} \\
\hline & & & Day 2 & Day 4 & \\
\hline & $\mu M$ & $\%$ & \multicolumn{2}{|c|}{$m g / 10^{6}$ cells } & \\
\hline & 0 & 100 & $2.40 \pm 0.30 *$ & $2.25 \pm 0.33$ & 9.24 \\
\hline \multirow[t]{3}{*}{ FIAU } & 0.1 & 101 & $2.41 \pm 0.16(0.4 \%)^{\ddagger}$ & $2.68 \pm 0.52(19.1 \%)$ & 9.69 \\
\hline & 1 & 118 & $2.58 \pm 0.29(7.5 \%)$ & $3.02 \pm 0.61(34.25 \%)$ & 14.40 \\
\hline & 10 & 86 & $3.38 \pm 0.30(40.8 \%)$ & $4.56 \pm 0.27(102.7 \%)$ & 22.28 \\
\hline \multirow[t]{3}{*}{ FMAU } & 0.1 & 100 & $2.38 \pm 0.34(0 \%)$ & $2.76 \pm 0.54(22.7 \%)$ & 9.48 \\
\hline & 1 & 97 & $2.46 \pm 0.29(2.5 \%)$ & $3.22 \pm 0.50(43.1 \%)$ & 16.33 \\
\hline & 10 & 100 & $3.62 \pm 0.16(50.8 \%)$ & $5.33 \pm 0.92(136.9 \%)$ & 23.54 \\
\hline \multirow[t]{3}{*}{$3 \mathrm{TC}$} & 0.1 & ND & $2.40 \pm 0.12(0 \%)$ & $2.39 \pm 0.12(6.2 \%)$ & ND \\
\hline & 1 & & $2.36 \pm 0.12(0 \%)$ & $2.44 \pm 0.18(8.4 \%)$ & \\
\hline & 1.0 & & $2.36 \pm 0.01(0 \%)$ & $2.35 \pm 0.08(4.4 \%)$ & \\
\hline
\end{tabular}

Values are mean of two experiments except $*$ data represents mean \pm SD of three different experiments. ${ }^{\ddagger}$ The number in the bracket is the percentage of increase on lactic acid production compare with control. $N D$, Not determined.

of herpes simplex virus and cytomegalovirus infections (18, 29) was recently reported to be also effective against HBV replication $(3,4)$. The anti-HBV activity of the 5 '-triphosphate form of FIAU is assumed to result from its selective inhibition of viral targets, possibly HBV DNA polymerase (30). In contrast to herpes simplex virus, HBV does not encode a deoxynucleoside kinase and therefore the activation of FIAU is mediated by host cell enzymes, including thymidine kinase, thymidylate kinase and pyrimidine diphosphate kinase leading to formation of FIAU-TP, the likely active metabolite. Unanticipated lethal toxicity after 8-12 wk of treatment with FIAU in HBV infected patients has led the scientific community to attempt to understand the possible molecular mechanism(s) of this FIAU-causing toxicity $(6,19)$.

Mitochondrial toxicity has been suggested to play a key role in this FIAU-causing liver failure $(6,7)$. Evidence for mitochondrial damage in FIAU-treated patients includes severe lactic acidosis with massive macro- and microvesicular steatosis in liver biopsies suggestive of a disturbance in energy metabolism processes in which mitochondria are usually involved. Furthermore, electron micrographs revealed enlarged and irregular mitochondria in those patients $(5,6)$.

In an attempt to elucidate FIAU-induced liver toxicity with possible molecular target sites, the present study examined the degree of toxicity of FIAU in a HepG2 cell line as well as potential mechanisms which may have led to impairment of cellular and mitochondrial functions in FIAU-treated patients. As shown in Fig. 1, a dose-dependent inhibition on cell growth was observed with FIAU and FMAU, a metabolite which was detected by our laboratory in biological fluids of FIAU-treated patients (19). Consistent with recently published data (30), FIAU was effectively phosphorylated to its triphosphate but rapidly plateaued to phosphate derivative levels well below those previously reported (30), probably reflecting our use of confluent rather than proliferating cells. A similar pattern profile was observed with FMAU, in agreement with the same affinity of these compounds for host phosphorylating enzymes (31). The degree of phosphorylation of FIAU and FMAU was not affected when metabolism was investigated in 2.2.15 cells which have integrated HBV genomic sequences and produce infectious virions (13). This data is consistent with the non induction of nucleoside kinases by HBV and raises the question as to whether these infected cell cultures metabolize FIAU in a similar fashion as those livers of HBV infected patients. Indeed, it is important to note that in these in vitro studies, only conversion of FIAU to FAU was observed while both FAU and FMAU are detected in biological fluids of FIAU treated patients (19).

Although inhibition of mtDNA synthesis by FIAU or incorporation of FIAU into the mitochondrial genome have been hypothesized, no data has yet been reported. In the present study, both FIAU and FMAU, at concentrations inhibiting more than $75 \%$ of cell growth, had no detectable effect on the mtDNA content of HepG2 cells after $14 \mathrm{~d}$ of continuous exposure to drugs, suggesting that FIAU and FMAU may not affect the quantitative synthesis of mtDNA.

Although incorporation of FIAU into total DNA has been previously reported $(32,33)$, it is yet unclear whether FIAU is able to incorporate into mtDNA and whether incorporation of that drug into nucleic acids is predominant in one of the two cellular compartments. In addition, no data are yet available on whether FMAU can also incorporate into either nuclear and mtDNA. In our studies, both radioactive FIAU and FMAU were detected in nuclear DNA and mtDNA and absolute values would suggest a preferential incorporation into nuclear DNA rather than mtDNA. However, mtDNA represents $<1 \%$ of total DNA in mammalian cells (34), suggesting that both FIAU and FMAU incorporate at a much higher rate into mtDNA than nuclear DNA. Consistent with previous studies which demonstrated that FIAU and FMAU are not subtrates for mitochondrial thymidine kinase (35), phosphorylation of these two compounds was not detected in isolated mitochondria of HepG2 cells (Fig. 2). Therefore, as suggested previously with ddC (36), a transport carrier on the mitochondrial membrane may be responsible for the uptake of intracellular FIAU and FMAU nucleotides toward the mitochondrial space resulting in a subsequent incorporation into mtDNA. In contrast to $2^{\prime}, 3^{\prime}$-dideoxynucleosides which lacks a free $3^{\prime}$-hydroxyl group, FIAU contains a $3^{\prime}$-hydroxyl group probably leading to incorporation into DNA at internucleotide linkages. This incorporation would result in unfunctional DNA at the transcriptional level and probably affect gene expression of nuclear and mtDNA which are 

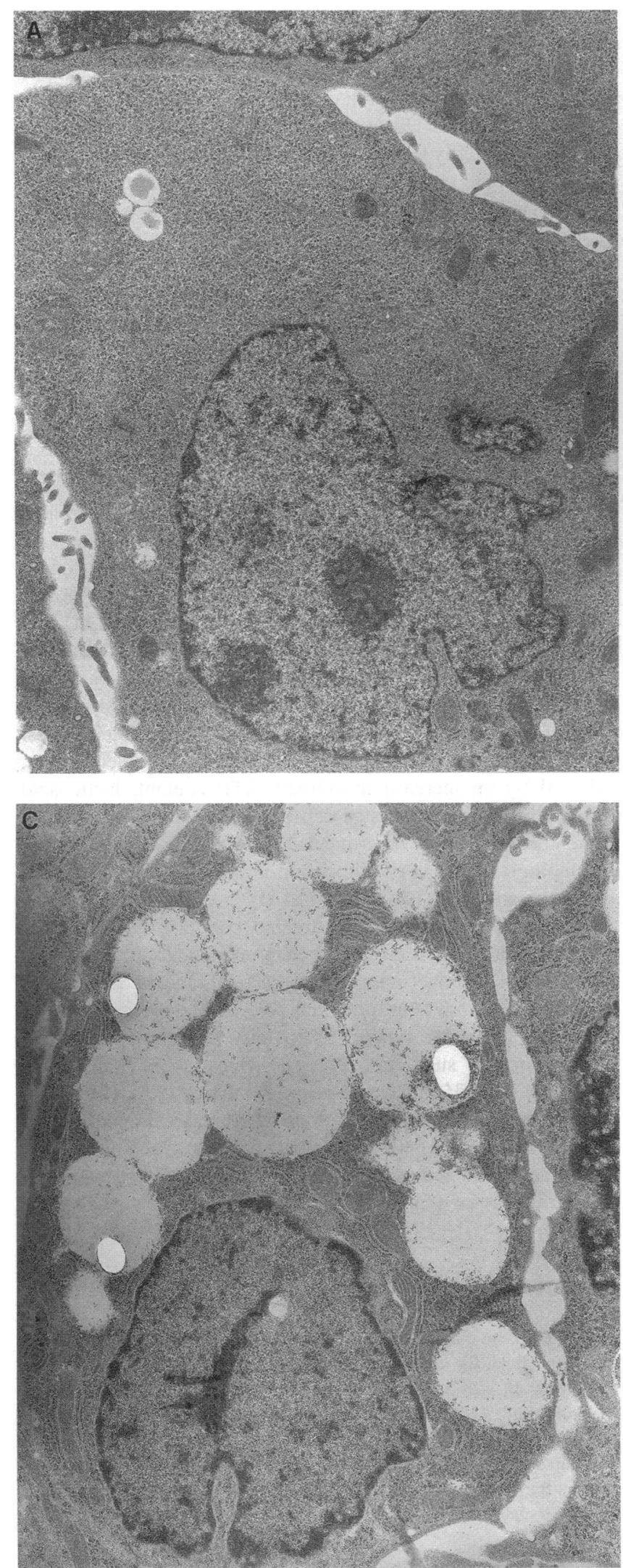

important for cell function and thereby leading to cell damage. The potential role of FIAU and FMAU incorporation into nucleic acids and into mtDNA in particular, in mediating toxicity of HepG2 cells is further suggested by their major effects on

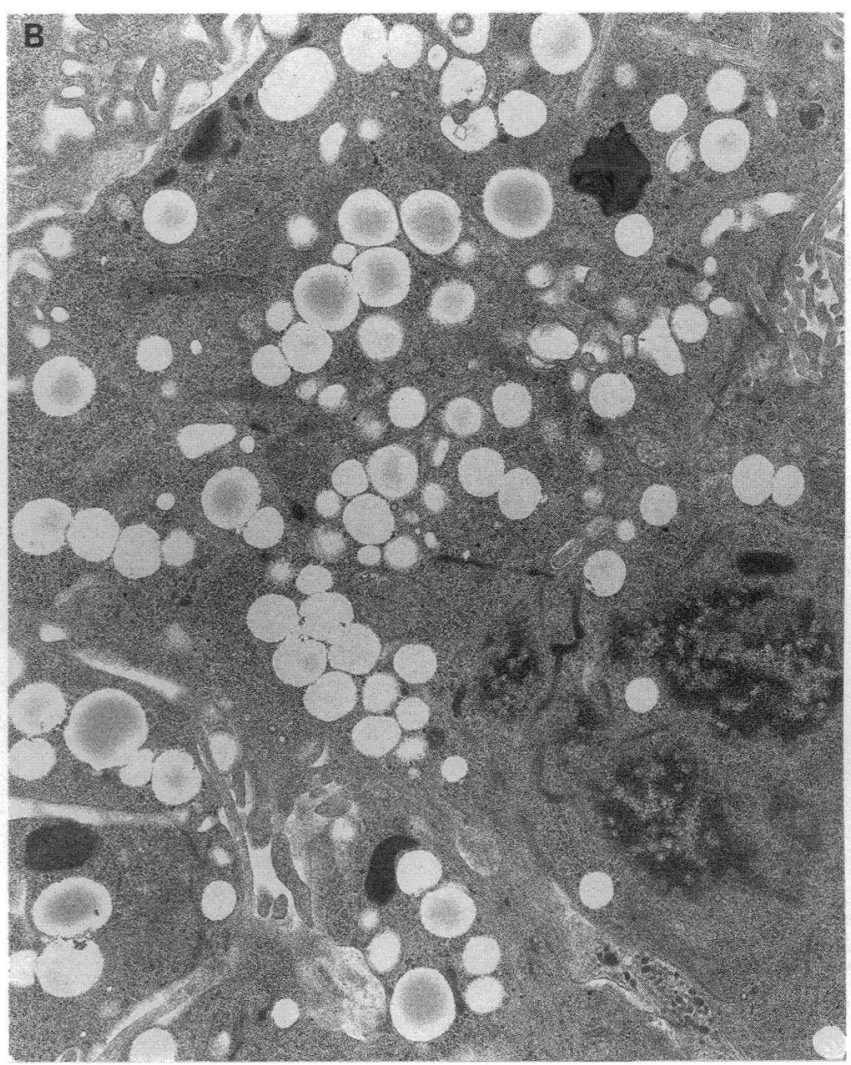

Figure 5. Electron micrograph of a control HepG2 cell $(A)$ and the same cell line incubated over $4 \mathrm{~d}$ with $10 \mu \mathrm{M}$ FIAU $(B)$ or $10 \mu \mathrm{M}$ FMAU (C). $\times 12,000$.

the cellular energy metabolism of the mitochondria. When a mitochondrial dysfunction occurs, cells can react in different ways to compensate the decreased mitochondrial function. For instance, glycolysis can be enhanced as reflected by an increase 

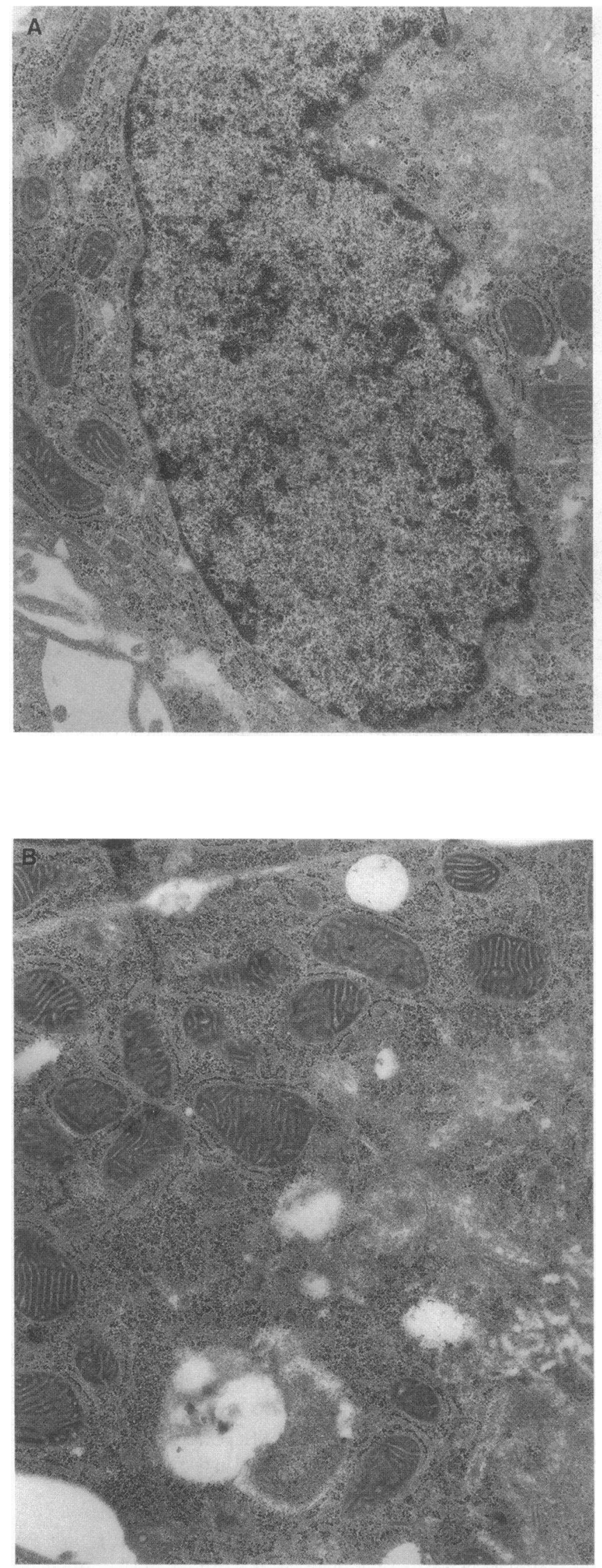

Figure 6. Electron microscopy evaluation of mitochondria in control HepG2 cell $(A)$ and cell exposed over $4 \mathrm{~d}$ with $10 \mu \mathrm{M}$ FIAU $(B)$. $\times 30,000$. in lactic acid production. A significant increase in lactic acid content was detected in HepG2 cells culture medium after $4 \mathrm{~d}$ exposure to FIAU or FMAU ( Table II), a phenomenon consistent with clinical observation of FIAU-treated patients. The cellular ATP content in HepG2 cells after $4 \mathrm{~d}$ treatment with FIAU or FMAU markedly increased in a dose-dependent manner, suggesting that the mitochondrial dysfunction induced by FIAU and FMAU might initiate a glycolysis acceleration as a compensatory mechanism leading to energy enchancement. Meanwhile, mitochondria may react in some way leading to an increased mitochondrial volume and mitochondria numbers per hepatocyte, similarly as observed with liver cirrhosis (37). Consistent with that hypothesis, mitochondria of HepG2 cells incubated with FIAU or FMAU were enlarged and displayed a higher cristae density (Fig. $4 \mathrm{~B}$ ) which also reflect the activation of compensatory energy mechanism. The electron micrographs (Fig. 3, B and $C$ ) further demonstrate that both FIAU and FMAU could cause micro- and macrovesicular steatosis in HepG2 cells as demonstrated in liver cells of FIAU-treated patients. The elevated cellular ATP levels concomittant to a possible disturbance in the TCA cycle in mitochondria could build up the steatosis which is a main route for energy storage.

In summary, the present data suggest that both FIAU and FMAU can cause mitochondrial dysfunction like ddC and ddI (38), but through different mechanisms. Notably, they do not decrease mtDNA replication but are incorporated into nuclear and mtDNA possibly resulting in unfunctional nucleic acids. There is a major disturbance in cellular energy metabolism, reflected by an increase in cellular ATP content, lactic acid production and higher cristae density of mitochondria. Furthermore, the micro and macrovesicular steatosis as well as the morphological change of mitochondria detected in HepG2 cells after exposure with FIAU and FMAU are consistent with the clinical observations in FIAU treated patients. These studies emphasize the importance of such biochemical studies in the development of novel entities for the treatment of viral infections and underlines the potential role of metabolites such as FMAU in a possible synergistic toxicity with the parent drug. The absence of such mitochondria effects with 3TC (Table II) and (-) -2',3'-dideoxy-5-fluoro-3'-thiacytidine (39), two nucleoside analogs being developed for the treatment of HIV and HBV infections (40-42) demonstrate that each nucleoside should be considered as a unique entity and further emphasizes the usefulness of that class of compound to treat such viral infections.

\section{Acknowledgments}

We would like to thank Eugene Arms for electron microscopy evaluation and Terri Hicks for preparing and editing the manuscript.

This work was supported in part by Public Health Service grants AI-33239 and AI-32775 (J. P. Sommadossi), AI-25899 (R. F. Schinazi ), by the Department of Veterans Affairs and the UAB Comprehensive Cancer Center, Core Facility for Electron Microscopy. J.-P. Sommadossi is the recipient of a Faculty Research Award from the American Cancer Society.

\section{References}

1. Hoofnagle, J. H., D. A. Shafritz, and H. Popper. 1987. Chronic type B hepatitis and the healthy HBsAg carrier state. Hepatology. 7:758-763.

2. Szmuness. W. 1978. Hepatocellular carcinoma and the hepatitis B virus: evidence for a causal association. Prog. Med. Virol. 24:40-69.

3. Fourel, I., O. Hantz, K. A. Watanabe, C. Jacquet, B. Chomel, J. J. Fox, and C. Trepo. 1990. Inhibitory effects of $2^{\prime}$-fluorinated arabinosyl-pyrimidine 
nucleosides on woodchuck hepatitis virus replication in chronically infected woodchucks. Antimicrob. Agents Chemother. 34:473-475.

4. Paar, D. P., T. M. Hooton, K. A. Smiles, A. Di Bisceglie, D. V. Havlir, D. D. Richman, D. R. Gretch, L. Corey, and S. E. Straus. 1992. The effect of FIAU on chronic hepatitis B virus (HBV) infection in HIV-infected subjects (ACTG 122b). The 32nd Interscience Conference on Antimicrobial Agents and Chemotherapy, Anaheim, CA. 264.

5. Dusheiko, G. M. 1994. Fialuridine toxicity: new hopes and false downs. International Antiviral News. 2(2):22-23.

6. Touchette, N. 1993. HBV-drug deaths prompt restudy of similar antivirals. J. NIH Research. 5:33-35.

7. Parker, W. B., and Y. C. Cheng. 1994. Mitochondrial toxicity of antiviral nucleoside analogs. J. NIH Research. 6:57-61.

8. Chen, C. H., and Y. C. Cheng. 1989. Delayed cytotoxicity and selective loss of mitochondrial DNA in cells treated with the anti-human immunodeficiency virus compound 2',3'-dideoxycytidine. J. Biol. Chem. 264:11934-11937.

9. Faulds, D., and R. N. Brogden. 1992. Didanosine-a review of its antiviral activity, pharmacokinetic properties and therapeutic potential in human immunodeficiency virus infection. Drugs. 44:94-116.

10. Dalakas, M. C., I. Illa, G. H. Pezeshkpour, J. P. Laukaitis, B. Cohen, and J. L. Griffin. 1990. Mitochondrial myopathy caused by long-term zidovudine therapy. N. Engl. J. Med. 322:1098-1105.

11. Faraj, A., D. A. Fowler, E. G. Bridges, and J. P. Sommadossi. 1994. Effects of $2^{\prime}, 3^{\prime}$-dideoxynucleosides on proliferation and differentiation of human pluripotent progenitors in liquid culture and their effects on mitochondrial DNA synthesis. Antimicrob. Agents Chemother. 38:924-930.

12. Aden, D. P., A. Fogel, S. Plotkin, I. Damjanov, and B. B. Knowles. 1979. Controlled synthesis of HBsAg in a differentiated human liver carcinoma-derived cell line. Nature (Lond.). 282:615-617.

13. Sells, M. A., A. Z. Zelent, M. Shvartsman, and G. Acs. 1988. Replication intermediates of hepatitis B virus in HepG2 cells that produce infectious virions. J. Virol. 62:2836-2844.

14. Darlington, G. J., J. H. Kelly, and G. J. Buffone. 1987. Growth and hepatospecific gene expression of human hepatoma cells in a defined medium. In Vitro Cell. Dev. Biol. 23(5):349-354.

15. Sassa, S., O. Sugita, R. A. Galbraith, and A. Kappas. 1987. Drug metabolism by the human hepatoma cell, HepG2. Biochem. Biophys. Res. Commun. 143:52-57.

16. Chou, T. C., A. Feinberg, A. J. Grant, P. Vidal, U. Reichman, K. A. Watanabe, J. J. Fox, and F. S. Philips. 1981. Pharmacological disposition of metabolic fate of 2 -fluoro-5-iodo-1- $\beta$-D-arabinofuranosylcytosine in mice and rats. Cancer Res. 41:3336-3342.

17. Philips, F. S., A. Feinberg, T. C. Chou, P. M. Vidal, T. L. Su, K. A. Watanabe, and J. J. Fox. 1993. Distribution, metabolism, and excretion of 1 (2-fluoro-2-deoxy- $\beta$-D-arabinofuranosyl) thymine and 1-(2-fluoro-2-deoxy- $\beta$-Darabinofuranosyl)-5-iodocytosine. Cancer Res. 43:3619-3627.

18. Schinazi, R. F., J. J. Fox, K. A. Watanabe, and A. J. Nahmias. 1986. Activities of 1-(2-deoxy-2-fluoro-beta-D-arabinofuranosyl)-5-iodocytosine and its metabolites against herpes simplex virus types 1 and 2 in cell culture and in mice infected intracerebrally with herpes simplex virus type 2. Antimicrob. Agents Chemother. 29:77-84.

19. Sommadossi, J. P. 1993. Dept. of Health and Human Services. Transcrip of FDA antiviral advisory committee meeting on FIAU toxicity. Transcript Dept. Health \& Human Services.

20. White, E. L., W. B. Parker, L. J. Macy, S. C. Shaddix, G. McCaleb, J. A. I. Secrist, R. Vince, and W. M. Shannon. 1989. Comparison of the effect of carbovir, AZT, and dideoxynucleoside trisphosphates on the activity of human immunodeficiency virus reverse transcriptase and selected human polymerases. Biochem. Biophys. Res. Commun. 161:393-398.

21. Anderson, S., A. T. Bankier, B. G. Barrell, M. H. L. de Brujin, A. R. Coulson, J. Drouin, I. C. Eperon, D. P. Nierlich, B. A. Roe, F. Sanger, P. H. Schreier, A. J. H. Smith, R. Staden, and I. G. Young. 1981. Sequence and organization of the human mitochondrial genome. Nature (Lond.). 290:457-465.

22. Moore, D. 1989. Preparation and analysis of DNA. In Current Protocols in Molecular Biology. F. M. Ausubel, R. Brent, R. E. Kingston, D. Moore, J. G. Seidman, J. A. Smith, and K. Struhl, editors. Current Protocols, Greene Publishing Associates, Inc. and John Wiley \& Sons, Inc., New York. Vol. 1. 2.1.1-2.1.3.

23. Welter, C., S. Dooley, and N. Blin. 1989. A rapid protocol for the purifica- tion of mitochondrial DNA suitable for studying restriction fragment length polymorphisms. Gene (Aust.). 83:169-172.

24. Chen, C. H., M. Vasquez-Padua, and Y. C. Cheng. 1991. Effect of antihuman immunodeficiency virus nucleoside analogs on mitochondrial DNA and its implication for delayed toxicity. Mol. Pharmacol. 39:625-628.

25. Smith, J. B., and L. Smith. 1990. Energy dependence of sodium-calcium exchange in vascular smooth muscle cells. Am. J. Physiol. 259(28):C302-309.

26. Stanley, P. E., and S. G. Williams. 1969. Use of the liquid scintillation spectrometer for determining adenosine triphosphate by the luciferase enzyme Anal. Biochem. 29:381-392.

27. Poulton, J., M. E. Deadman, and R. M. Gardiner. 1989. Duplications of mitochondrial DNA in mitochondrial myopathy. Lancet. 1:236-240.

28. Watanabe, K. A., U. Reichman, J. Kosaku, C. Lopez, and J. J. Fox Nucleosides. 1979. 110. Synthesis and antiherpes virus activity of some 2 '-fluoro2'-deoxyarabinofuranosylpyrimidine nucleosides. J. Med. Chem. 22:21-24.

29. Drew, W. L., R. Miner, and D. King. 1991. Antiviral activity of FIAU (1-[2'deoxy-2'fluoro-1-beta-D-arabinofuranosyl]-5-iodo-uridine) on strains of cytomegalovirus sensitive and resistant to ganciclovir. J. Infect. Dis. 163:13881389.

30. Staschke, K. A., J. M. Colacino, T. E. Mabry, and C. D. Jones. 1994 The in vitro anti-hepatitis B virus activity of FIAU [1-(2'-deoxy-2'-fluoro-1- $\beta$ D-arabinofuranosyl-5-iodo) uracil] is selective, reversible, and determined, at leas in part, by the host cell. Antiviral Research 23:45-61.

31. Chen, M. S., L. A. Amico, and D. J. Speelman. 1984. Kinetics of the interaction of monophosphates of the antiviral nucleosides 2 '-fluoro-1- $\beta$-D-arabinofuranosylpyrimidine and (E)-5-(2-bromovinyl)-2'-deoxyuridine with thymidylate kinases from Vero cells and herpes simplex virus types 1 and 2. Antimicrob. Agents Chemother. 26:778-780.

32. Grant, A. J., A. Feinberg, T. C. Chou, K. A. Watanabe, J. J. Fox, and F. S. Philips. 1982. Incorporation of metabolites of 2'-fluoro-5-iodo-1-beta-Darabinofuranosylcytosine into deoxyribonucleic acid of neoplastic and norma mammalian tissues. Biochem. Pharmacol. 31:1103-1108.

33. Chen, M. S., M. V. Nostrand, and S. C. Oshana. 1986. Quantitative determination of antiviral nucleoside analog in DNA. Anal. Biochem. 156:300305.

34. Clayton, D. A. 1982. Replication of animal mitochondrial DNA. Cell. 28:693-705.

35. Cheng, Y. C., G. Dutschman, J. J. Fox, K. A. Watanabe, and H. Machida 1981. Differential activity of potential antiviral nucleoside analogs on herpes simplex virus-induced and human cellular thymidine kinases. Antimicrob. Agents Chemother. 20:420-423.

36. Chen, G. H., and Y. C. Cheng. 1992. The role of cytoplasmic deoxycytidine kinase in the mitochondrial effects of the anti-human immunodeficiency virus compound 2',3'-dideoxycytidine. J. Biol. Chem. 267(5):2856-2859.

37. Krahenbuhl, S., and J. Reichen. 1992. Adaptation of mitochondrial metabolism in liver cirrhosis. Different strategies to maintain a vital function. Scand. $J$. Gastroenterol. 27(193):90-96.

38. Sommadossi, J.-P. 1993. Nucleoside analogues: similarities and differences. Clin. Infect. Dis. 16(suppl 1):S7-S15.

39. Sommadossi, J.-P., R. F. Schinazi, A. Di Bisceglie and L. Cui. 1994 Impairment of mitochondrial function by FIAU and its in vivo metabolite FMAU do not correlate with mitochondrial DNA content in HepG2 cells. The VII International Conference on Antiviral Research, Charleston, SC., February 27-March 4, 1994.

40. Tyrrel, D. L. J., M. C. Mitchell, R. A. DeMan, S. W. Schalm, J. Maln and H. J. Thomas, J. Fevery, F. Nevens, P. Beranek and C. Vicary. 1993. Phase II trial of lamuvidine for chronic hepatitis B. Hepatology. 18:224.

41. Furman, P. A., M. Davis, D. C. Liotta, M. Paff, L. W. Frick, D. J. Nelson, R. E. Dornsife, J. A. Wurster, L. J. Wilson, J. A. Fyfe, J. V. Tuttle, W. H. Miller L. Condreay, D. R. Averett, R. F. Schinazi, and G. R. Painter. 1992. The antihepatitis $B$ virus activities, cytotoxicities, and anabolic profiles of the $(-)$ and (+) enantiomers of cis-5-fluoro-1-[2-(hydroxymethyol)-1,3-oxythiolan-5-yl]cytosine (FTC). Antimicrob. Agents Chemoter. 36:2686-2692.

42. Schinazi, R. F., A. McMillan, D. Cannon, R. Mathis, R. M. Lloyd, A Peck, J.-P. Sommadossi, M. St. Clair, J. Wilson, P. A. Furman, G. Painter, W.-B. Choi, and D. C. Liotta. 1992. Selective inhibition of human immunodeficiency viruses by racemates and enantiomers of cis-5-fluoro-1-[2-(hydroxymethyl)-1,3-oxathiolan-5-yl]cytosine. Antimicrob. Agents Chemother. 36:24232431 . 